\title{
A Comparative Study on Chemical Characterization and Properties of Surface Active Compounds From Gram-positive Bacillus and Gram-negative Ochrobactrum Strains Utilizing Pure Hydrocarbons and Waste Mineral Lubricating Oils
}

\section{Ishika Saha}

University of Calcutta - Rajabazar Science College Campus

Sriparna Datta ( $\nabla$ sriparnadatta2014@gmail.com )

University of Calcutta - Rajabazar Science College Campus https://orcid.org/0000-0002-3380-1950

\section{Dipa Biswas}

University of Calcutta - Rajabazar Science College Campus

\section{Dipanjan Sengupta}

University of Calcutta - Rajabazar Science College Campus

\section{Research Article}

Keywords: Surface active compounds, Emulsification Index, Environment friendly molecules, Industrial waste mineral lubricating oil, Bioremediation, biomaterials

Posted Date: December 29th, 2021

DOI: https://doi.org/10.21203/rs.3.rs-1193026/v1

License: (c) (1) This work is licensed under a Creative Commons Attribution 4.0 International License. Read Full License 


\section{Abstract}

Mineral lubricating oils are widely used in various industrial sectors for their applications in maintenance and functioning of machineries. However, indiscriminate dumping of these used oils has resulted in polluting the natural reservoirs which subsequently destroys ecological balance. Bacteria can emulsify or lower surface tension between phases of immiscible substrates and can acquire them as their carbon and energy sources. Such a phenomenon is mediated by synthesis of extracellular polymeric substances which can function as eminent surface active compounds based on their surfactant or emulsifying nature. The comparison between bacterial strains (Gram-positive Bacillus stratosphericus A15 and Gramnegative Ochrobactrum pseudintermedium $\mathrm{C} 1$ ) on utilisation of pure straight chain hydrocarbons, waste mineral lubricating oils as sole carbon source and chemical characterization of the synthesized surface active compounds is studied. Characterization analysis by Ultraviolet Visible spectrophotometry, Fouriertransform infrared spectroscopy, Nuclear Magnetic Resonance spectroscopy, Carbon-Hydrogen-Nitrogen analysis has given detailed structural elucidation of surface active compounds. The contrasting nature of bacterial strains in utilisation of different hydrocarbons of spindle oil was observed in Gas Chromatography-Mass Spectroscopy. The variation between both strains in utilisation of hydrocarbons can be manifested in a difference in chemical structure and properties of the synthesized surface active compounds. Scanning Electron Microscopy gives detailed insight into the difference in morphological nature of the compounds. The utilisation of these lubricating oils can address waste disposal problem and offer an economical feasible approach for bacterial synthesis of surface active compounds. Additionally, their distinctive nature and properties can maneuver applications in bioremediation of toxic environmental pollutants and as biomaterials in pharmaceutics.

\section{Introduction}

The detrimental effect on environment due to mismanagement of waste disposal has been a matter of concern since many decades. Broadly, wastes can be classified into hazardous and non-hazardous category. The hazardous wastes are generated from automobiles, textiles, petroleum refineries, plastic and fiber manufacturers, paper and pulp industries, tanneries, leather and metallurgical industries. According to EPA (Environmental Protection Agency, USA) hazardous wastes pose a serious threat to environment, human life and can also create ecological imbalance. The generated wastes may come in any form like liquids, solids, gases or sludges (USEPA 2018; Soundari et al. 2020). One such hazardous waste is industrial mineral lubricating oils which contributes up to $76 \%$ of world's waste oil disposal (Kajdas 2014). Automobiles, textiles, metallurgical and other industrial sectors depending on axles, turbines etc. generally dump waste mineral lubricating oils in natural reservoirs. Apart from such malpractice, human error and equipment malfunction has led to oil spillage accidents which can deteriorate the environment (Bhattacharya and Biswas 2014a; Meiners 2020; Guerin 2008). Mineral lubricating oils mainly consist of straight chain and branched hydrocarbons, $\mathrm{PAH}$ (Poly Aromatic Hydrocarbons), PCB (Poly Chloro Biphenyls), heavy metals thus it falls under the hazardous category (Bhattacharya et al. 2015). Irrational disposal of such oils in natural reservoirs can cause 
bioaccumulation of non-biodegradable, carcinogenic chemical components in both aquatic and terrestrial animals and plants which ultimately pose serious health effect in human (Bhattacharya et al. 2015b; Kajdas 2014). Conventional methods like thermal destruction or acid clay process are inefficient and can cause further environmental pollution. Moreover, dumping of highly viscous and dense oils on the surface can lead to eutrophication thus blocking penetration of sunlight into the interior of the water bodies. Further, deprivation of sunlight results in inhibition of photosynthesis thus disrupting aquatic ecosystem (Down to earth 2021). The alarming situation has opened a domain of research that aims in seeking newer environment friendly alternative methods to combat pollution caused by oil or petroleumhydrocarbons. Bioremediation by utilizing oil degrading bacteria has been a topic of great interest since 1980s (Panday and Arora 2020). Pseudomonas, Halomonas, Acinetobacter, Rhodococcus, Bacillus, Geobacillus species are some of the common hydrocarbon metabolizing bacteria reported in previous literature works (Bonilla et al., 2005; Vasconcellos et al. 2011; Martínez-Checa et al. 2002; Zhou et al. 2018).

In India, the demand of lubricating oils increases by 10 lakh tons per year. The share for automobile lubricants is $60 \%$, while the remaining $40 \%$ share accounts for industrial lubricants (Selvi et al. 2013). The hydrocarbons present in waste industrial mineral lubricating oils can serve as effective carbon source for the synthesis of bacterial extracellular polymeric substances (EPS) (Misra and Pandey 2005; Lin et al. 2010; US EPA 2004; Das and Chandran 2011). EPS mediates easier uptake of such hydrocarbons by acting as surface active compound (SAC) consisting of both lipophilic and hydrophilic moieties and are excellent in lowering surface tension between two interfaces or forming emulsions (Vasconcellos et al. 2011). The high molecular weight bioemulsifiers are more efficient in stabilizing oil in water or water in oil emulsions, on the contrary, biosurfactants reduce surface and interfacial tension between different phases like liquid-liquid, liquid-air and liquid-solid (Uzoigwe et al. 2015). The use of synthetic emulsifiers or surfactants in various commercial sectors like food and cosmetics, environmental bioremediation and agriculture, pharmaceuticals, petroleum and paints are common. However, most of these chemicals are hazardous and can persist in environment for a long time due to their low biodegradability (Kosaric 1992). Comparatively, environment friendly SACs can provide a better alternative for usage in commercial sectors (Saha et al. 2020).

Different myriad species of bacteria like Acinetobacter, Bacillus, Variovorax, Azotobacter, Pseudomonas, Ochrobactrum, Geobacillus, Paenibacillus, Exiguobacterium, Halomonas, Alcaligenes, Aeribacillus species has been reported in literature as producer organisms of varied surface-active compounds (Bhattacharya et al. 2014b; Sana et al. 2018; Cai et al. 2017; Zhou et al. 2018; Nerurkar et al. 2009; Toledo et al. 2008; Zheng et al. 2012). In this context, published previous reports regarding synthesis of different surface active compounds by utilisation of varied carbon sources i.e., hydrocarbons and simple sugars by Ochrobactrum pseudintermedium C1 were studied (Bhattacharya et al. 2014b; Sengupta et al. 2019). In another study, Bacillus stratosphericus A15 has been reported to synthesize a lipopeptide SAC by utilisation of fish fat (Sana et al. 2018). 
Although many bioemulsifiers and biosurfactants has been reported in scientific works with various carbon sources the utilisation of hydrocarbons by two bacterial species as their sole carbon source has not been explored before. Our work compares between gram-negative Ochrobactrum pseudintermedium $\mathrm{C} 1$ and gram-positive Bacillus stratosphericus A15 on the utilisation of pure straight chain hydrocarbons and industrial waste mineral lubricating oils for production of SACs. The work further investigates whether the difference in cell wall morphology of bacteria strains can influence their uptake of hydrocarbons and chemical composition, characteristics of SACs. The utilisation of waste mineral lubricating oil also bring double benefits because it provides an economical carbon source for production of biodegradable SACs and additionally the work also provides a better alternative in waste oil disposal management.

\section{Experimental Procedure}

\section{Chemicals and media required for the study}

Waste mineral lubricating oils like spindle oil, cutting oil, compressor oil, hydraulic oil was collected from an oil factory named Asianol Pvt Ltd., Kolkata, India. Pure alkane hydrocarbons like nonane, tetradecane, hexadecane, eicosane, octacosane was procured from Sigma Aldrich Co. USA. Apart from these, all the other chemical reagents and growth media needed for the study were purchased from Hi-media Laboratories and Sigma Aldrich Co.

\section{Screening of bacterial strains}

The bacterial strains Bacillus stratosphericus, Ochrobactrum pseudintermedium, Pseudomonas aeruginosa, Bacillus cereus available in the laboratory of Department of Chemical Technology, University of Calcutta were carefully preserved and sub-cultured in nutrient agar slants.

\section{Culture conditions, maintenance and production of surface active compounds (SACs)}

The growth of the bacterial strains and subsequent production of SACs was done employing Bushnell Haas broth (BH) [in g/L: $1.0 \mathrm{KH}_{2} \mathrm{PO}_{4}, 1.0 \mathrm{~K}_{2} \mathrm{HPO}_{4}, 1.0 \mathrm{NH}_{4} \mathrm{NO}_{3}, 0.2 \mathrm{MgSO}_{4} .7 \mathrm{H}_{2} \mathrm{O}, 0.02 \mathrm{CaCl}_{2} .2 \mathrm{H}_{2} \mathrm{O}, 0.05$ $\mathrm{FeCl}_{3} \cdot 6 \mathrm{H}_{2} \mathrm{O} ; \mathrm{pH} 7.0 \pm 0.2$. Erlenmeyer flasks containing broth were sterilized prior to the experiment. Pure hydrocarbons and waste mineral lubricating oils as sole carbon sources was added to the flasks. After mixing, fresh overnight bacterial inoculum suspended in $\mathrm{BH}$ broth $\left(\mathrm{OD}_{600}=1.0\right)$ was added to the flasks

\section{Parameters maintained for synthesis of bacterial SACs in culture broth}

To determine the optimal culture conditions, parameters like temperature, $\mathrm{pH}$, incubation period, percentage of carbon source and aeration were considered. The following conditions were maintained for growth of bacterial strains and synthesis of SACs: $25-40{ }^{\circ} \mathrm{C}, \mathrm{pH} 2-10,1-15$ days, $2-10 \%$ of waste mineral lubricating oils $(\mathrm{w} / \mathrm{v})$. The $\mathrm{pH}$ of culture medium was adjusted by adding $1 \mathrm{~N} \mathrm{NaOH}$ and $1 \mathrm{~N} \mathrm{HCl}$ solutions with gradual stirring. The flasks were then incubated in orbital shaker (ORBITEK-LJE incubator) under 
aerobic conditions. Control flasks (non-inoculated flasks) were incubated in the same conditions to verify that no abiotic loss take place in aerobic conditions.

\section{Extraction and isolation of SACS}

The method described by Bhattacharya et al. 2014b and Sengupta et al. 2019 was followed for isolation and purification of the compounds. The culture supernatant was subsequently treated with hexane to extract residual oil and hydrocarbons (Adebusoye et al. 2007). The precipitates were then collected in tubes and were kept in vacuum desiccators filled with $\mathrm{CaCl}_{2}$ as the desiccant and were pistol dried for further analysis.

\section{Influence of SACs on cell surface hydrophobicity}

The adhesion of bacterial cells to hydrocarbons was evaluated by modifying the technique of Rosenberg et al., 1980 for measuring cell surface hydrophobicity in presence of a hydrophobic substrate. Growing of bacterial strains in Bushnell Haas broth $(\mathrm{BH})$ enriched with spindle oil for 2 weeks was followed by harvesting of cells at 6000 RPM for 20 min and resuspending cells in sterile broth. An aliquot of $500 \mu \mathrm{l}$ of test oils was added to $5 \mathrm{ml}$ of bacterial cell suspension and vortexed. Optical density of the aqueous phase at $600 \mathrm{~nm}$ was taken. Bacterial adhesion to hydrocarbons (BATH) is expressed as-

\section{$B A T H=\left\{1-\left(\frac{\mathrm{A} 600 \text { of the aqueous phase }}{\mathrm{A} 600 \text { of the initial cell suspension }}\right)\right\} \times 100$}

\section{Assessing the surfactant and emulsifying property of SACs}

The surfactant property of compounds was evaluated by measuring surface tension activity of culture supernatant by using a tensiometer (Data physics DCAT 11, Germany) at room temperature by following du Nuoy ring method (Lunkenheimer and Wantke 1981) using distilled water $\left(71 \mathrm{mN} \mathrm{m}^{-1}\right)$ as reference. The emulsifying potential of aqueous extracts of SACs was determined by performing the emulsification assay or otherwise termed as "emulsification index" (EI). To $2 \mathrm{ml}$ of the aqueous mixture of SACs, $2 \mathrm{ml}$ of hydrophobic substrate was added. The mixture was vortexed for 2 minutes and was kept in undisturbed condition for 24 hours. Tetradecane, hexadecane, diesel, kerosene, vacuum gas oil, engine oil, crude oil, and mustard oil were chosen as hydrophobic substrates. The emulsification index was measured according to the following equation (Cooper and Goldenberg 1987).

$$
E I(\%)=\frac{\mathrm{h} \text { emulsion }}{\mathrm{h} \text { total }} \times 100
$$

where, $\mathrm{h}_{\text {emulsion }}$ is the height of emulsion layer formed in between immiscible phases by emulsifying property of SAC and $\mathrm{h}_{\text {total }}$ is the total height of the liquid mixture.

Structural elucidation of the SACs produced by bacterial strains utilizing waste mineral lubricating oil as substrates 
The carbohydrate content was estimated by following phenol-sulphuric acid method for total carbohydrates according to Dubois et al. 1956 and the protein content was estimated according to Lowry's method for proteins (Lowry et al. 1951) by using Ultraviolet-visible spectrophotometer (UV-1800, Shimadzu corp, Japan). The Folch et al. 1957 method was followed for lipid estimation.

Characterization studies

The purified, dried SACs extracted from the cell free supernatant was subjected to various characterization studies for detailed structural insight.

Fourier Transform Infrared (FTIR) spectroscopy

To $1 \mathrm{mg}$ of the SAC, $100 \mathrm{mg}$ of potassium bromide was mixed. The mixture was grounded finely taking the aid of mortar and pestle. The finely grounded mixture was then subjected to 9 metric ton pressure for $1 \mathrm{~min}$. Similarly, potassium bromide pellet was prepared for the other samples. The pellets were then inserted into Perkin Elmer (USA) Spectrum version 10.5.1 and the respective IR spectra is obtained. All the spectrums were recorded at room temperature, in the range $4000-400 \mathrm{~cm}^{-1}$.

Nuclear Magnetic Resonance (NMR) spectroscopy

Understanding of the chemical constitution of the extracted SACs was done by Nuclear Magnetic Resonance spectroscopy. SACs were dissolved in deuterated chloroform, $\mathrm{CDCL}_{3}$ (for the compounds produced utilizing pure hydrocarbons as sole carbon source) and deuterated dimethyl sulfoxide, DMSOd6 (for the compounds produced utilizing lubricating oils as sole carbon source) and vortexed thoroughly. The samples were then subjected to Bruker Avance 400 Spectrometer (400 MHz NMR) and Jeol ECZ 500 spectrometer (500 MHz NMR) for $\mathrm{H}^{1} \mathrm{NMR}$ analysis up to spectral width of $15 \mathrm{ppm}$. The chemical shifts were recorded as ppm relative to the resonance of TMS as the internal standard.

Elemental (CHN) analysis

The carbon, hydrogen and nitrogen content of purified SACs was estimated by using a Thermofinnigan Flash 1112 Elemental Analyser.

Morphological and microstructural analysis by Scanning Electron Microscopy (SEM)

The surface morphology and micro structure of the purified SACs was observed by Zeiss Evo 18 Special Edition, Zeiss, Germany. The samples were mounted on the metal stub and fixed with $3 \%$ glutaraldehyde solution for 2 hours. Sequential dehydration by $20 \%, 40 \%, 70 \%$ and $90 \% \mathrm{vol} / \mathrm{vol}$ ethanol followed by sputtering with platinum and images were recorded.

Thermal stability studies 
Thermal stabilities of $12 \mathrm{mg}$ dried, purified SACs were determined using Perkin Elmer Diamond TG/DTA by using Thermogravimetric (TG) and Differential thermal (DT) analysis. Initial temperature and final temperatures of the samples were $30^{\circ} \mathrm{C}$ and $800^{\circ} \mathrm{C}$ respectively. The temperature was raised by maintaining the heating rate at $10^{\circ} \mathrm{C} / \mathrm{min}$. TG and DT analysis was done with gradual increase in temperature, plotting weight percentage and heat flow against temperature respectively.

Analysis of mineral lube oil before and after bacterial utilisation by GC-MS

The residual oils before and after bacteria utilisation was extracted from the culture medium by following the methods of Bhattacharya et al. 2015 and Sengupta et al. 2019. All the samples were then diluted 10 times by HPLC-grade $n$-hexane. Hexane extracts of the sample $(1 \mu \mathrm{l})$ were then injected for analysis by using a Thermo Scientific Trace 1300 series gas chromatograph and DB5MS column. Helium was used as the carrier gas with flowrate $1.5 \mathrm{ml} / \mathrm{min}$. Comparative analysis between two bacterial strains regarding the fraction of waste spindle oil getting utilised as sole carbon source i.e., Bacillus stratosphericus A15 and Ochrobactrum pseudintermedium $\mathrm{C} 1$ was studied. Chromatograms were analyzed by Chromeleon 7.0 program and a library (NIST 2007) search was performed for the identification of peaks.

\section{Results}

\section{Selection of bacteria}

Two bacterial strains i.e., Gram positive Bacillus stratosphericus A15 and Gram negative Ochrobactrum pseudintermedium $\mathrm{C} 1$ showing better potential in production of surface active compounds were selected, sub-cultured and were preserved in sterile nutrient agar slants at $4^{\circ} \mathrm{C}$.

\section{Selection of carbon source}

$\mathrm{BH}$ broth was enriched with two types of hydrocarbons i.e., pure straight chain alkanes and waste mineral lubricating oils as carbon sources. The carbon source influencing maximum bacterial growth and SAC synthesis was selected. Ochrobactrum pseudintermedium $\mathrm{C} 1$ and Bacillus stratosphericus A15 showed optimal growth when hexadecane and nonane were the carbon sources respectively. Among the waste mineral lubricating oils like compressor, spindle, cutting and hydraulic oil, spindle oil produced maximum growth and yield of SACs by both the bacterial strains.

\section{Parameters for production of SACs}

$\mathrm{pH}$ of the culture medium

By modulation of the $\mathrm{pH}$ values the metabolic process and subsequently the yield of SAC is also influenced (Jin and Kirk 2018). Majority of the bacteria has shown growth under neutral conditions. The study was performed under varying $\mathrm{pH}$ conditions $(\mathrm{pH} 2-10)$. However, yield of surface active compounds in culture medium increased at slightly alkaline and neutral pH for Bacillus stratosphericus A15 and 
Ochrobactrum pseudintermedium $\mathrm{C} 1$ respectively as shown in Table 1. In acidic conditions, both the strains have shown no growth.

Temperature of the medium

Temperature plays an important role in maintaining the physiological condition and metabolic activity of the cells. Maximum biodegradation by bacteria occurs between temperatures 25 and $37^{\circ} \mathrm{C}$ when crude oil is used as substrate. Optimal temperature conditions are necessary for the proper functioning of the enzymes which are responsible for breakdown of complex hydrocarbon substrates followed by simultaneous synthesis of surface active compounds (Das and Chandran 2011). In this study, the optimal growth of Ochrobactrum pseudintermedium $\mathrm{C} 1$ was found to be between $32-34^{\circ} \mathrm{C}$ while the production of SACs is facilitated at slightly higher temperatures of $35-37^{\circ} \mathrm{C}$ while Bacillus stratosphericus A15 produce SACs at temperature range between $32-33.5^{\circ} \mathrm{C}$.

Percentage of carbon source, incubation time on bacterial growth and yield of SAC

It was observed that $4 \%$ of the pure and waste hydrocarbon as sole carbon sources are optimum for the growth of bacterial strains and subsequent production of SACs. In this study, bacterial strains grown in a wide range of pure straight chain hydrocarbons i.e., starting from hexane (C-6) to octacosane (C-28) has shown difference in growth and yield of SAC. It was observed that bacterium Ochrobactrum pseudintermedium $\mathrm{C} 1$ can degrade long chain hydrocarbons (C-14 to $\mathrm{C}-18$ ) and produce SAC whereas, on the contrary, Bacillus stratosphericus A15 can degrade short chain hydrocarbons (C-6 to C-12) and produce SAC. Identical pattern in degradation of alkanes was observed in a study reported by Zheng et al. 2011. The growth of these bacterial strains was monitored by measuring the optical density. The maximum optical density was observed between $10^{\text {th }}-12^{\text {th }}$ days of incubation with aeration rate at 90 100 rpm when waste hydrocarbons (spindle oil) and pure straight chain alkane hydrocarbons (C-9 and C16) were present as carbon sources (Figure 1a). Interestingly, quite similar growth pattern and production of SAC was observed in another study reported by Cai et al., 2017 when hexadecane was used as carbon source in the medium. The yield of SACs was highest during the stationary phase of bacterial growth curve i.e., between $12^{\text {th }}-13^{\text {th }}$ days for Bacillus stratosphericus A15 and $14^{\text {th }}-15^{\text {th }}$ days for Ochrobactrum pseudintermedium $\mathrm{C} 1$ respectively. The SAC 3 produced by strain A15 utilizing spindle oil was ethanol precipitated and the total yield was around $150 \mathrm{mg} / \mathrm{L}$ after hexane purification. On the other hand, strain $\mathrm{C} 1$ has produced SAC 4 with total yield of $300 \mathrm{mg} / \mathrm{L}$ following the same process. The ethanol precipitated SACs after isolation and extraction has shown an amorphous nature (Figure 1 bi, bii). These compounds were then subjected to various structural, chemical and morphological studies to further evaluate their surface activity and to elucidate their chemical structure and composition.

Assessing the emulsifying, surfactant and cell surface hydrophobicity of SACs

Gram positive Bacillus stratosphericus A15 and Gram negative Ochrobactrum pseudintermedium $\mathrm{C} 1$ has shown $38 \%$ and $56 \%$ adherence to waste spindle oil during incubation (Table 2 ). Such phenomenon is further explained by the tendency of the strain Bacillus stratosphericus A15 to produce SAC 1 and SAC 3 
after utilisation of nonane and waste spindle oil with the capacity of lowering the surface tension from 71 $\mathrm{mN} / \mathrm{m}$ to $53 \mathrm{mN} / \mathrm{m}$ and $51.7 \mathrm{mN} / \mathrm{m}$ respectively. On the contrary, SACs produced by Ochrobactrum pseudintermedium $\mathrm{C} 1$ has shown no significant reduction in surface tension. SAC 2 and SAC 4 synthesized from strain Ochrobactrum pseudintermedium $\mathrm{C} 1$ could only reduce to $63.9 \mathrm{mN} / \mathrm{m}$ and 61 $\mathrm{mN} / \mathrm{m}$ when hexadecane and waste spindle oil respectively were present as carbon sources (Figure 2 bii). The findings are in correlation with earlier reported studies where petroleum hydrocarbons were present in the growth medium (Toledo et al., 2008, Bhattacharya et al., 2014b). However, Ochrobactrum pseudintermedium $\mathrm{C} 1$ has produced surface active compounds with emulsifying properties. SACs produced by strain $\mathrm{C} 1$ has shown better results when diesel, engine oil and mustard oil were used as hydrophobic substrates in comparison to SACs produced by strain A15. The SAC produced by strain C1 with waste spindle oil as the carbon source has shown better emulsifying activity against diesel $(2 \%)$ vacuum gas oil (2.5\%), hexadecane (10\%), tetradecane (12.5\%), mustard oil (37.5\%), motor oil (35\%), crude oil (50\%) and engine oil (88 \%) in comparison to strain A15 (Figure 2 bi). It was observed that Ochrobactrum pseudintermedium $\mathrm{C} 1$ synthesizes SAC 4 that displayed stable emulsions for up to 48 hours. Bioemulsifier produced by Paenibacillus sp. has shown similar emulsifying activity against variety of substrates ranging from pure to aromatic hydrocarbons as well as against mixed hydrocarbons like crude oil, produced in a medium containing glucose and hydrocarbons (Gudiña et al. 2015).

Chemical composition and structural elucidation of SACs

Chemical analysis, spectrophotometry methods and $\mathrm{CHN}$ analysis

Carbohydrate estimation of the surface active compounds as shown in Table 3 was found to be less compared to other organic constituents. SAC 4 produced by Ochrobactrum pseudintermedium $\mathrm{C} 1$ has $1.85 \%$ of carbohydrate content. On the contrary, SAC 3 produced by Bacillus stratosphericus A15 has carbohydrate content below methodology detection level of 1\% (Figure 3 ai). The protein content of SAC 3 and SAC 4 were found to be 3.4 and $6 \%$ respectively (Figure 3 aii). The result obtained by Folin-Lowry's method was further corroborated by $\mathrm{CHN}$ analysis. SAC 4 produced by strain $\mathrm{C} 1$ has shown the following parameters:

C- $12.42 \%, \mathrm{H}-3.99 \%, \mathrm{~N}-0.805 \%$ while SAC 3 produced by strain A15 with its following estimation: $\mathrm{C}-4.356 \%$, $\mathrm{H}-2.663 \%$ and $\mathrm{N}-0.620 \%$ has shown less carbon, hydrogen and nitrogen content when compared to SAC 4. Apart from carbohydrates and protein SAC 3 and SAC 4 constitutes $43 \%$ and $80 \%$ lipids respectively as estimated by Folch method as shown in Table 3. The results obtained can be further interpreted by FTIR and NMR analysis. Similar composition of SACs was reported by Luna et al., 2007 and Zheng et al., 2012. Apart from lipids, carbohydrates and proteins, inorganic constituents may comprise the remaining portion of SACs as reported by Kourmentza et al. 2019.

Characterization of SACs by FTIR studies

The surface active compounds produced by bacterial strain A15 (SAC 1) and C1 (SAC 2) utilising pure hydrocarbons nonane and hexadecane respectively were primarily characterized by FTIR followed by 
detailed structural elucidation by NMR. It is worth mentioning that when compared to IR spectra of pure nonane and hexadecane, significant differences were observed in the synthesized surface active compounds as shown in Table 4a. The broad strong bands near $3300-3450 \mathrm{~cm}^{-1}$ are attributed to the presence of hydroxyl -OH stretch. The presence of alkyne stretch is indicated by less intense bands near $2200 \mathrm{~cm}^{-1}$. Further down the spectra, strong bands at $1650 \mathrm{~cm}^{-1}$ in both the structures corresponds to $\mathrm{C}=\mathrm{C}$ stretch of alkenes or carbonyl stretching of amides. The bands at $1385 \mathrm{~cm}^{-1}$ suggests the presence of $\mathrm{CH}_{3}$ bending in the finger print region. The sharp bands near $1050 \mathrm{~cm}^{-1}$ suggests the presence $\mathrm{C}-\mathrm{O}$ stretch of ether in both the structures (Kodali et al. 2009, Amral et al. 2006). Presence of small bands between $858-934 \mathrm{~cm}^{-1}$ in the fingerprint region is a characteristic feature indicating the presence of carbohydrates (Figure 2 ai).

The FTIR spectra of surface active compounds produced by strain A15 (SAC 3) and strain C1 (SAC 4) utilizing pure alkane hydrocarbons and waste spindle oil has revealed some differences given in Table 4b. Presence of hydroxyl $-\mathrm{OH}$ is common in both the structures along with $\mathrm{C}=\mathrm{C}$ stretch of alkenes or carbonyl stretching of amides $(\mathrm{C}=0)$ (Amral et al. 2006). There is presence of sharp bands at 2925 and $2855 \mathrm{~cm}^{-1}$ in SAC 4 which corresponds to the $\mathrm{C}-\mathrm{H}$ asymmetric stretch of $\mathrm{CH}_{2}$ and $\mathrm{CH}_{3}$ groups respectively (Beltrani et al. 2015; Gudina et al. 2015) suggesting the characteristic presence of fatty acids in SAC 4. Less intense bands near $2200 \mathrm{~cm}^{-1}$ were seen in both SAC 3 and SAC 4 denoting alkyne stretch. The $\mathrm{C}=0$ stretch of amide functional group was further supported by presence of band at $1461 \mathrm{~cm}^{-1}$ in SAC 4 which corresponds to $\mathrm{C}-\mathrm{N}$ group of amides (Amral et al. 2006). In the fingerprint region, ether functional group and anomeric carbon of carbohydrates are present. (Bhattacharya et al. 2014b; Sengupta et al. 2019; Beltrani et al. 2015) (Figure 2 aii).

Characterization of SACs by ${ }^{1} \mathrm{H}-\mathrm{NMR}$ studies

Proton NMR study of SAC 1 and SAC 2 produced by bacterial strains A15 and C1 utilizing pure hydrocarbons nonane and hexadecane as sole carbon sources respectively has shown distinct differences in structures when compared to proton NMR spectra of pure hydrocarbons (Figure 4 ai, aii). Presence of aliphatic saturated chain of lipids, unsaturated hydrocarbons and ether functional group in both the structures was evident as shown in Table 4a. Signals between 1.8-2.1 ppm confirms unsaturation in structures. A strong signal at $2.984 \mathrm{ppm}$ in SAC 2 can be assigned to the protons attached to carbonyl group. The presence of such signal is not distinct in SAC 1. Presence of isopropyl groups in SAC 1 is attributed by signals between 3.690-3.755 ppm.

Differences in structures of bacterial surface-active compounds as revealed in $\mathrm{H}^{1}$-NMR analysis by utilising spindle oil as the sole carbon source is given in Table 4b. Multiple signals between 0.7-1.4 ppm denote protons in aliphatic saturated chain of lipid moiety i.e., alkyl $\mathrm{CH}_{3}, \mathrm{CH}_{2}$ and $\mathrm{CH}$ or cholesterol in the structures (Watts 2013). This is followed by unsaturated protons or carbonyl protons at 1.8-2.4 ppm and protons of ether functional group at 3.6-3.8 ppm. Further downfield, signals between 4.2-5 ppm can confirm the presence of anomeric sugars (Duus et al. 2000). Presence of isopropyl groups in SAC 4 was 
evident by characteristic signals between 1.409-1.475 ppm. However, in SAC 3 less distinct signal for isopropyl group was observed in the region between 1.4-1.5 ppm. The presence of isopropyl group may suggest the branched nature of the structures (Figure 4 bi, bii).

\section{Microstructural studies of SACs by Scanning Electron Microscopy}

The SACs produced by strain has shown some contrasting differences. SAC produced by strain A15 has displayed few elongated crystalline rod-like structures in low magnifications whereas in higher magnifications presence of spherical structures was more prominent. SAC produced by strain $\mathrm{C} 1$ has shown irregular spherical structures in lower magnifications whereas in higher magnifications few crystalline rod- like structures and globular spherical structures adjacent to web like porous matrix was observed. (Figure 5).

Thermal stability studies of SACs

Thermogravimetric analysis (TGA) of SACs produced by bacterial strains A15 and C1 by utilising waste spindle oil has shown initial weight reduction in between $80-150^{\circ} \mathrm{C}$. This phenomenon can be attributed due to loss of moisture and solvents in both cases. Thermogram of samples displayed similar gradual downward curve with increase in temperature thus implying decomposition of organic matter. During the second phase i.e., from $150-350^{\circ} \mathrm{C}$ rapid degradation in both the samples was observed. Maximum degradation has started from $350^{\circ} \mathrm{C}$ and continued till $800^{\circ} \mathrm{C}$. Upon completion of the analysis, residual weights of SAC 3 and SAC 4 have accounted for $58 \%$ and $66 \%$ respectively as shown in Table 5 suggesting more thermal resistant behavior of SAC 4 when compared to SAC 3 (Figure 6 a). The thermal degradation pattern observed in case of extracellular polymeric substance produced by Oceanobacillus iheyensis was found to be same to that of SACs produced by bacteria strains Bacillus stratosphericus A15 and Ochrobactrum pseudintermedium C1 (Kavita et al. 2014). In another study, an emulsifier based extracellular polymeric substance has shown a similar thermal degradation curve (Sengupta et al. 2019). Differential Thermal Analysis (DTA) graphs of both the samples validates with their respective TGA graphs. The endothermic peak near $100^{\circ} \mathrm{C}$ is characteristic of dehydration reaction. Another significant exothermic peak was observed at $338.06^{\circ} \mathrm{C}$ and $380.54{ }^{\circ} \mathrm{C}$ for SAC 3 and SAC 4 respectively corresponding to organic oxidation of both the compounds (Figure $6 \mathrm{~b}$ ). The ability to withstand such higher temperatures can make them suitable for application in various commercial sectors (Oliveira et al. 2020).

GC-MS analysis of waste industrial mineral lubricating oils before and after bacterial utilisation GC-MS analysis of bacterial strains utilised fraction of waste spindle oil when compared to the fraction before utilisation, has revealed some interesting differences. There has been complete disappearance of few peaks corresponding to cyclohexane, hexadecynol and heptadecyne derivatives in the chromatogram of Ochrobactrum pseudintermedium C1 utilised spindle oil fraction; whereas there has been decrease in concentration of hexadecynal, eicosane derivatives in $\mathrm{C} 1$ utilised fraction of spindle oil (Figure 6 ciii and diii). On the other hand, no such disappearance of peaks was observed in the chromatogram of spindle 
oil utilised fraction by Bacillus stratosphericus A15. Moreover, while comparing chromatograms of both the bacterial strains, less degradation capability of hydrocarbons by strain A15 was observed (Figure 6 cii and dii). The peak corresponding to hexadecane derivative i.e., hexadecynal was observed in bacterial strains utilised chromatograms. However, the concentration of this hexadecane derivative in $\mathrm{C} 1$ utilised fraction of waste spindle oil was much less compared to strain A15 utilised fraction suggesting better utlisation of long chain hydrocarbons by strain $C 1$ (Figure $6 c$ and Figure $6 d$ ). The presence of hexadecanal and dodecadienol derivatives in $\mathrm{A} 15$ and $\mathrm{C} 1$ utilised fraction respectively suggests that strain A15 is capable of utilising short chain hydrocarbons while strain $\mathrm{C} 1$ has shown capability in utilising both short and long chain hydrocarbons when it was subjected to a complex hydrocarbon carbon source, i.e., waste spindle oil. Presence of organic acid hexadecadienoate and alcoholic derivatives i.e., dodecadienol, octadecatetraenol in the chromatogram of spindle oil utilised by strain $\mathrm{C} 1$ also suggests bacterial metabolism and bioconversion of complex hydrocarbon substrates into intermediate compounds. The efficiency of bacterial strain Ochrobactrum pseudintermedium $\mathrm{C} 1$ in degrading hydrocarbons of waste oils has been previously reported in similar studies (Bhattacharya and Biswas 2014; Bhattacharya et al. 2015, Sengupta et al. 2019). Hydrocarbon metabolism and production of intermediate compounds by Bacillus sp. has also been reported (Sabina et al. 2014).

\section{Discussion}

So far, many studies regarding uptake of n-alkanes as the sole carbon source by bacteria has been studied. Bacteria may do so by adherence of cell to hydrocarbon droplets or by surfactant/emulsifier production which facilitates easier consumption of such immiscible carbon sources (Rojo 2009). Bacteria producing such amphiphilic molecules possessing emulsifying and surfactant properties by degradation of hydrocarbons has been reported. However, the chemical architecture, nature and properties of such molecules vary and is mainly dictated by the growth parameters and nutrient source (Rosenberg and Ron 1999; Calvo et al. 2009). For instance, several species of Ochrobactrum (Sengupta et al. 2019; Bhattacharya et al. 2014b; Bezza et al. 2015; Zarinviarsagh et al. 2017) and Bacillus (Toledo et al. 2008; Parthipan et al. 2017; Ayed et al. 2013; Sana et al. 2018) when subjected to culture medium enriched with varied substrates, simultaneous production of surface active compounds were reported. However, few hydrocarbons can show toxicity which can ultimately limit growth of such bacteria strains. Majority of the bacteria tend to degrade simpler carbon sources rather than complex hydrocarbon carbon sources (Sengupta et al. 2018; Bhattacharya et al. 2015). It is necessary to mention that by certain evolutionary strategies, some bacteria can show affinity towards oil or hydrocarbons and consume them as their necessary energy and carbon source. They are called "hydrocarbonoclastic" bacteria for their role in bioremediation of hydrophobic pollutants like petroleum hydrocarbons and discharged oils (Xu et al. 2018; Yakimov et al. 2007). In context of environmental bioremediation, such eco-friendly practices can be done by employing bacteria alone or by their metabolites (Datta et al. 2020; Sengupta et al. 2018). For instance, in previous studies Ochrobactrum pseudintermedium $\mathrm{C} 1$ has produced an extracellular polymeric substance (EPS) which help in enhancing emulsification of complex hydrocarbon wastes like engine and cutting oil (Bhattacharya et al. 2014; Sengupta et al. 2019). The EPS was initially coined as 
"exopolysaccharide" by Sutherland in 1972 to describe high molecular weight sugars which is alternatively termed as "extracellular polymeric substances" being primarily composed of polysaccharides, proteins, lipids and nucleic acids. These amphiphilic molecules are mainly produced at the late logarithmic or during stationary phase of growth curve (Sengupta et al. 2018). Bacteria thrive in adverse natural environments by production of such secondary metabolites which enable them to retain moisture, acquire nutrients, prevent osmotic stress, resist high and cold temperatures and aid in biofilms formation. In laboratory, apart from physical chemical factors, carbon source in the medium, genetic character and growth phase of the bacterial strain can determine the chemical composition and properties of extracellular polymeric substances (Datta et al. 2020; Saha et al. 2020). Apart from emulsification of hydrophobic substances, EPS may even contain surfactant properties as reported in previous works (Uzoigwe et al., 2015). Detailed structural characterization and chemical composition by various spectroscopic and microscopic methods can provide insight into their functional attributes which are unique and sometimes superior to the polysaccharides derived from plants (Saha et al. 2020; Singha 2012).

Bacteria synthesized SACs from pure and waste hydrocarbons as carbon sources

In this present study, comparison between two bacterial strains i.e., Gram positive Bacillus stratosphericus A15 and Gram negative Ochrobactrum pseudintermedium C1 on utilisation of both pure and waste hydrocarbon substrates and subsequent evaluation of chemical structure and properties of the produced surface-active compounds has also been done. The two bacterial strains have shown contrasting pattern of growth on Bushnell-Hass broth with hydrocarbons as evident from their growth curves. After a short lag phase, the cells of strain $\mathrm{C} 1$ have quickly shifted towards exponential phase and gradually towards the stationary phase. While strain A15 have shown a prolong lag phase, followed by a gradual shifting towards exponential and stationary phase. Since surface active compounds are categorized as bacteria derived secondary metabolites, better growth and utlisation of hydrocarbons as sole carbon sources are required by cells for increasing the bioavailability of these immiscible substances. Therefore, strain $\mathrm{C} 1$ has shown better growth and yield of SACs while utilising hydrocarbons when compared to strain A15. Utilisation of petroleum hydrocarbons like crude oil followed by synthesis of surface active compounds from bacteria or consortium has been studied in previous works (Cooper and Goldenberg 1987, Bhattacharya et al. 2019).

Interpretation of characterization studies for structural elucidation, morphological, tensioactive and thermal stability properties of surface active molecules

The FTIR and $\mathrm{H}^{1}$-NMR characterization has revealed the presence of some additional functional groups ($\mathrm{OH}$ of alcohols, $-\mathrm{OCH}_{3}$ of ethers and $-\mathrm{CO}$ of amides) which are not otherwise present in linear chain alkanes like nonane and hexadecane. Hence, it can be said that enriching of Bushnell Haas broth with these alkane hydrocarbons lead to simultaneous production of amphiphilic SACs thus increasing bioavailability of these insoluble hydrocarbons as carbon source (Cai et al. 2017). Similar structural attributes can be observed when Bacillus stratosphericus A15 and Ochrobactrum pseudintermedium C1 
are subjected to complex waste hydrocarbons like spindle oil as the sole carbon source. SAC 3 and SAC 4 produced by strains $\mathrm{A} 15$ and $\mathrm{C} 1$ has shown the chemical composition denoting $80 \%$ lipids, $6 \%$ proteins and $1.85 \%$ carbohydrates and $43 \%$ lipids, $3.4 \%$ proteins and $0.85 \%$ carbohydrates respectively. The FTIR and $\mathrm{H}^{1}$-NMR study has revealed the presence of aliphatic groups in the structures along with the hydrophilic groups like hydroxyl, carbonyl and ether thus confirming the results obtained in chemical analysis (Ortega-de la Rosa et al. 2018). Further, surface active compounds from Ochrobactrum pseudintermedium $\mathrm{C} 1$ has shown emulsification against a wide range of substrates like pure straight chain hydrocarbons (hexadecane and tetradecane), petroleum fractions (diesel, engine oil, vacuum gas oil, burnt oil and crude oil), and edible oil (mustard oil). Emulsification of pure aromatic hydrocarbons like benzene and toluene was not observed. The results so obtained suggest that surface active compounds from Ochrobactrum pseudintermedium $\mathrm{C} 1$ has shown more efficiency in emulsifying both aliphatic and waste hydrocarbons. The high lipid content of the SAC 4 produced by strain $\mathrm{C} 1$ along with functional groups present in proteins and carbohydrates might have contributed to its emulsification property. On the contrary, presence of less lipophilic groups in SAC 3 produced by strain A15 might be the reason for its surface tension lowering property $(50 \mathrm{mN} / \mathrm{m})$ when waste spindle oil and nonane were the carbon sources (Nerurkar et al. 2009). The difference in surface active properties can be further understood by the adhesion characteristics of individual bacterial strains to hydrocarbons. The lowering of surface tension by SACs produced by Bacillus stratosphericus A15 can be due to adhesion of SACs to the bacterial outer surface and directing the hydrophilic part outwards thus decreasing cell surface hydrophobicity or due to alterations in cell surface functional groups after the production of these compounds. On the contrary, increased and rapid adhesion by cell surface to waste spindle oil can indicate the ability of Ochrobactrum pseudintermedium $\mathrm{C} 1$ to produce SACs that can emulsify the hydrocarbon substrate into small droplets (Kaczorek et al. 2018). The concomitant production of SACs with emulsifying properties can facilitate easier consumption of waste spindle as carbon source. Moreover, higher percentage of lipids indicates presence of aliphatic groups like $-\mathrm{CH}_{3},-\mathrm{CH}_{2}$ and $-\mathrm{CH}$ as evident from FTIR spectrum which might impart thermal stability to SAC 4 when compared to SAC 3 . The elemental analysis has also shown high carbon, hydrogen and nitrogen content in SAC 4 that can further establish its emulsification potential and structural stability at high temperatures. On the contrary, less thermally stable characteristic of SAC 3 can be attributed to its low lipid content as evident from elemental analysis. Further, the SEM images suggest the morphological and microstructural differences in SACs produced by Bacillus stratosphericus A15 and Ochrobactrum pseudintermedium $\mathrm{C} 1$. The presence of distinct irregular web like matrix can imply the presence of lipids in SAC 4. In SAC 3, such structural morphology was less prominent thus indicating its less lipid content when compared to SAC 4. SEM specimens of bacterial EPS has shown similar web like fibrillar formation signifying entrapment sites of bacterial cells (Goh 2005). The globular structures in both SACs can be attributed to the presence of functional groups in proteins and carbohydrates (Bhattacharya et al., 2014b). Visual examination reveals high number of globular structures in SAC 4 when compared to SAC 3 . The morphological differences thus correlate with the structural elucidation of the structures obtained by chemical analysis, FTIR, $\mathrm{H}^{1}$-NMR. The characterization analysis thus suggest that the compounds are composed of mixtures of polysaccharides and proteins with aliphatic chains of lipids as backbone. The varied percentages of 
lipids, proteins and polysaccharides impart the molecules its distinctive characteristics (surfactant, emulsification potential and thermal stability).

Interpretation of GC-MS studies of residual waste spindle oil before and after bacterial utilisation

GC-MS studies provide a detailed insight into the differential uptake between two bacterial strains in utilisation of hydrocarbons present in waste spindle oil. The abundant presence of organic acids, aldehydes and alcoholic intermediate products in the utilised fractions suggest that bacterial strains can undergo beta oxidation after consuming long chain compounds in waste spindle oil which is the sole carbon and energy source (Bhattacharya and Biswas 2014). Notable mentions are presence of hexadecynal, hexadecadienoate and complete degradation of hexadecynol derivative in the Ochrobactrum pseudintermedium $\mathrm{C} 1$ utilized fraction of waste spindle oil which suggest that the presence of the organic acid hexadecadienoate can get reduced to hexadecynal, hexadecynol by enzymatic reactions. Quite similarly, in a study by Adlan et al. 2020 has reported that hexadecenoate gets reduced to hexadecanal which subsequently gets converted to pentadecane and carbon monoxide. The difference in concentration of hexadecynal can establish better utilisation of long chain hydrocarbons present in waste spindle oil by Ochrobactrum pseudintermedium $\mathrm{C} 1$ when compared to Bacillus stratosphericus A15. Intermediate products like organic acids formed from enzymatic reduction of long, medium and short chain alkanes can also provide carbon and energy source to the bacterial strains for facilitating the synthesis of SACs. Complete disappearance of some peaks corresponding to heptadecane and hexadecane by Ochrobactrum pseudintermedium $\mathrm{C} 1$ further establishes its better efficiency in metabolism of long chain hydrocarbon and subsequent synthesis of SACs.

\section{Conclusion}

The study focusses on comparison between Bacillus stratosphericus A15 and Ochrobactrum pseudintermedium $\mathrm{C} 1$ on utilisation of various types of hydrocarbons and evaluation of the differences in structural and surface active properties of the produced compounds. Waste mineral lubricating oils discharged from various industrial sectors can act as a suitable carbon source for cost effective synthesis of surface active molecules and thereby help in minimizing wastes while simultaneously combating pollution. Apart from exhibiting tensioactive and thermal stability properties, the presence of certain functional groups in the structure may render these eco-friendly molecules to seek promising outcomes in biomedical applications and environmental bioremediation.

\section{Declarations}

\section{Acknowledgement}

The authors thankfully acknowledge University Grants Commission of India (UGC) UPE II and SAP for providing the financial and academic support in completing the study. The authors are grateful to the following : (i) Professor Sujoy Kumar Das Gupta and Smriti Ranjan Maji (Technical Officer-I) for 
providing GC-MS facility and technical assistance at Bose Institute, Kolkata (ii) Indian Institute of Science, Bangalore for providing NMR facility and Mr. Ajay Dutta for the technical assistance (iii) Department of Polymer Science and Technology, University of Calcutta for providing FTIR facility (iv) SN Bose National Centre for Basic Sciences, for providing TGA facility (v) Indian Institute of Technology, Bombay for providing CHN facility (vi) Department of Chemical Technology, University of Calcutta and (vii) Centre for Research in Nanoscience and Nanotechnology, University of Calcutta for providing the necessary technical facilities and assistance in completing the study.

\section{Funding}

The authors gratefully acknowledge the financial assistance provided by University Grants Commission of India (UGC) UPE II.

Statements and Declarations Funding Financial assistance for conducting the entire study has been received from University Grants Commission of India (UGC) UPE II Conflict of interest The authors declare that they have no conflict of interest. Ethical Approval This article does not contain any studies with human participants or animals performed by any of the authors. Author contribution The study was conceptualized by Sriparna Datta. The methodology of the study was developed by Sriparna Datta, Ishika Saha and Dipanjan Sengupta. Formal analysis and investigation of the study was done by Ishika Saha. Original draft of the manuscript was prepared by Ishika Saha. Revision and editing of the manuscript were done by Sriparna Datta, Dipa Biswas and Dipanjan Sengupta. The study was done under the supervision of Sriparna Datta and Dipa Biswas. The funding acquisition and infrastructural support for conducting the study was arranged by Sriparna Datta and Dipa Biswas.

\section{References}

Adebusoye SA, llori MO, Amund OO, Teniola OD, Olatope SO (2007) Microbial degradation of petroleum hydrocarbons in a polluted tropical stream. World J Microbiol Biotechnol 23: 11491159.https://doi.org/10.1007/s11274-007-9345-3

Adlan NA, Sabri S, Masomian M, Ali M, Rahman R (2020) Microbial Biodegradation of Paraffin Wax in Malaysian Crude Oil Mediated by Degradative Enzymes.

Front microbial11: 565608. https://doi.org/10.3389/fmicb.2020.565608

Amaral PFF, Silva JD, Lehocký M, Barros-Timmons A, Coelho M, Marrucho I, Coutinho J (2006) Production and characterization of a bioemulsifier from Yarrowia lipolytica. Process Biochem 41:18941898.https://doi.org/10.1016/j.procbio.2006.03.029

Ayed $\mathrm{H}$, Jridi M, Maalej $\mathrm{H}$, Hmidet N (2014) Characterization and stability of biosurfactant produced by Bacillus mojavensis A21 and its application in enhancing solubility of hydrocarbon. J Chem Technol Biotechnol 89. 10.1002/jctb.4192. 
Banat IM, Satpute SK, Cameotra SS, Patil R, Nyayanit NV (2014) Cost effective technologies and renewable substrates for biosurfactants production. Front Microbiol 5:697. doi:

10.3389/fmicb.2014.00697. PMID: 25566213; PMCID: PMC4264478.

Beltrani T, Chiavarini S, Cicero DO, Grimaldi M, Ruggeri C, Tamburini E, and Cremisini C (2015) Chemical characterization and surface properties of a new bioemulsifier produced by Pedobacter sp. strain MCC-Z. Int J Biol Macromol 72: 1090-1096. https://doi.org/10.1016/j.ijbiomac.2014.10.025

Bezza FA, Beukes M, Chirwa EMN (2015) Application of Biosurfactant Produced by Ochrobactrum intermedium CN3 for Enhancing Petroleum Sludge bioremediation. Process Biochem:50 (11) 1911-1922. http://dx.doi.org/10.1016/j.procbio.2015.07.002

Bhattacharya M, Biswas D (2014a) Enhancement of waste engine oil biodegradation by optimization of media using factorial design study. Indian J. Biotechnol.13: 293-300.

Bhattacharya M, Biswas D, Sana S, Datta S (2015) Biodegradation of waste lubricants by a newly isolated Ochrobactrum sp. C1. 3 Biotech 5: 807-817. https://doi.org/10.1007/s13205-015-0282-9

Bhattacharya M, Biswas D, Sana S, Datta S (2014b) Utilization of waste engine oil by Ochrobactrum pseudintermedium strain $\mathrm{C} 1$ that secretes an exopolysaccharide as a bioemulsifier. Biocatal Agric Biotechnol3:167-176. 10.1016/j.bcab.2014.09.002.

Bhattacharya M, Guchhait S, Biswas D, Singh R (2019) Evaluation of a microbial consortium for crude oil spill bioremediation and its potential uses in enhanced oil recovery. Biocatal Agric Biotechnol 18: 101034. 10.1016/j.bcab.2019.101034.

Bonilla M, Olivaro C, Corona M, Vazquez A, Soubes M (2005) Production and characterization of a new bioemulsifier from Pseudomonas putida ML2. J Appl Microbiol 98(2):456-63. doi: 10.1111/j.13652672.2004.02480.x. PMID: 15659200.

Brzeszcz J and Kaszycki P (2018) Aerobic bacteria degrading both n-alkanes and aromatic hydrocarbons: an undervalued strategy for metabolic diversity and flexibility. Biodegradation 29:359407. https://doi.org/10.1007/s10532-018-9837-x

Cai Q, Zhang B, Chen B, Zhu Z, and Zhao Y (2017) A novel bioemulsifier produced by Exiguobacterium sp. strain N4-1P isolated from petroleum hydrocarbon contaminated coastal sediment. RSC Adv 7: 4269942708.https://doi.org/10.1039/C7RA07411E

Calvo C, Manzanera M, Silva-Castro GA, Uad I, González-López J (2009) Application of bioemulsifiers in soil oil bioremediation processes. Future prospects. Sci Total Environ 407(12):3634-40. doi: 10.1016/j.scitotenv.2008.07.008. Epub 2008 Aug 22. PMID: 18722001.

Cooper DG and Goldenberg BG (1987) Surface-active agents from two bacillus species. Appl. Environ. Microbiol 53(2): 224-229. https://doi.org/10.1128/aem.53.2.224-229.1987 
Das N and Chandran P (2011) Microbial degradation of petroleum hydrocarbon contaminants: an overview. Biotechnol Res Int 2011:941810. doi: 10.4061/2011/941810. Epub 2010 Sep 13. PMID: 21350672; PMCID: PMC3042690.

Datta S, Sengupta D, Saha I (2020) Bacterial Metabolites for Removal of Toxic Dyes and Heavy Metals. In: Inamuddin AMI, Lichtfouse E, Asiri AM (eds) Methods for Bioremediation of Water and Wastewater Pollution. Environmental Chemistry for a Sustainable World, Vol 51 pp 85-115. Springer, Cham https://doi.org/10.1007/978-3-030-48985-4_4.

Down to Earth (2021) Explaining the chemistry of oil spill.

https://www.downtoearth.org.in/classroom/explaining-the-chemistry-of-an-oil-spill-30725

Dubois M, Gilles KA, Hamilton J, Rebers PA, Smith F (1956) Colorimetric method for determination of sugar and relative substances Anal.Chem.28: 350-366.https://doi.org/10.1021/ac60111a017

Duus JØ, Gotfredsen CH, Bock K (2000) Carbohydrate Structural Determination by NMR Spectroscopy: Modern Methods and LimitationstChem Rev: 100 (12), 4589-4614. DOI: 10.1021/cr990302n

Edward A, Melchias G, Prabhu J, Wilson A, Anbananthan V and Sivaperumal K (2011) Detection of exopolysaccharides/bioemulsifier producing bacterial isolates from petroleum contaminated soil. Int $\mathrm{J}$ Biol Technol 2: 1-7.

Farias CBB, Almeida FCG, Silva IA, Souza TC, Meira HM, Silva R, Luna JM (2021) Production of green surfactants: Market prospects. Electron J Biotechnol 51 (2021): 28-39 https://doi.org/10.1016/j.ejbt.2021.02.002

Folch J, Lees M, Stanley GS (1957) A simple method for the isolation and purification of total lipids from animal tissues. J.Biol.Chem 226: 497-509.

Fracchia L, Cavallo M, Martinotti M, Banat I (2012) Biosurfactants and Bioemulsifiers Biomedical and Related Applications -Present Status and Future Potentials. 10.5772/23821.

Garcia INS and Oliveira VM (2013) Microbial Hydrocarbon Degradation: Efforts to Understand Biodegradation in Petroleum Reservoirs. In: Chamy R and Rosenkranz F (eds) Biodegradation Engineering and Technology, Intech Open, DOI: 10.5772/55920. hydrocarbon-degradation-efforts-tounderstand-biodegradation-in-petroleum-reservoirs.

Goh KKT, Haisman DR, Singh H (2005) Examination of exopolysaccharide produced by Lactobacillus delbrueckii subsp. Bulgaricus using confocal laser scanning and scanning electron microscopy techniques. Journal of Food Science 70: 224-229.

Gudiña E, Pereira J, Costa A, Evtuguin D, Teixeira J, Rodrigues L (2015) Novel bioemulsifier produced by a Paenibacillus strain isolated from crude oil. Microb. Cell Factories 14: 14. 10.1186/s12934-015-0197-5. 
Guerin TF (2008) Environmental liability and life-cycle management of used lubricating oils. J Hazard Mater 160: 256-64. 10.1016/j.jhazmat.2008.03.029.

Jin Q and Kirk M (2018) pH as a Primary Control in Environmental Microbiology: 1. Thermodynamic Perspective. Front Environ Sci 6.https://doi.org/10.3389/fenvs.2018.00021

Kaczorek E, Pacholak A, Zdarta A, Smułek W (2018) The Impact of Biosurfactants on Microbial Cell Properties Leading to Hydrocarbon Bioavailability Increase. Colloids and Interfaces 2(3):1-22. 10.3390/colloids2030035.

Kajdas C (2014) Used Oil Disposal and Collection. In: Mang T (eds) Encyclopedia of Lubricants and Lubrication. Springer, Berlin, Heidelberg. https://doi.org/10.1007/978-3-642-22647-2_310

Karina S and Stephen RE (2019) Sustainable microbial biosurfactants and bioemulsifiers for commercial exploitation. Process Biochem 85:143-155 https://doi.org/10.1016/j.procbio.2019.06.027

Kanamarlapudi S \& Muddada S (2017) Characterization of Exopolysaccharide Produced by Streptococcus thermophilus CC30. BioMed Res Int 2017: 4201809. https://doi.org/10.1155/2017/4201809

Kavita K, Singh VK, Mishra A, Jha B (2014) Characterisation and anti-biofilm activity of extracellular polymeric substances from Oceanobacillus iheyensis. Carbohydr Polym 30: 101:29-35. doi: 10.1016/j.carbpol.2013.08.099. Epub 2013 Sep 9. PMID: 24299745.

Kodali VP, Das S, Sen R (2009) An exopolysaccharide from a probiotic: Biosynthesis dynamics, composition and emulsifying activity. Food Res Int42(5-6):695-699. DOI: 10.1016/j.foodres.2009.02.007.

Kosaric N (1992) Biosurfactants in industry. Pure Appl Chem 64(11), 1731-1737. https://doi.org/10.1351/pac199264111731.

Kourmentza C, Araujo D, Sevrin C, Roma-Rodriques C, Lia Ferreira, J, Freitas F, Dionisio M, Baptista PV, Fernandes AR, Grandfils C, Reis, M. (2019) Occurrence of non-toxic bioemulsifiers during polyhydroxyalkanoate production by Pseudomonas strains valorizing crude glycerol byproduct. Bioresource technology 281: 31-40. https://doi.org/10.1016/j.biortech.2019.02.066.

Lin CW, Chen LH, I YP, Lai CY (2010) Microbial communities and biodegradation in lab-scale BTEXcontaminated groundwater remediation using an oxygen-releasing reactive barrier. Bioprocess biosyst eng 33(3): 383-391. https://doi.org/10.1007/s00449-009-0336-7.

Lowry OH, Rosebrough NJ, Farr AL, Randall RJ (1951) Protein measurement with the Folin phenol reagent. J Biol Chem 193(1):265-75. PMID: 14907713.

Luna A, Esparza GF, Cañizares-Villanueva R, Rodriguez Vazquez, R (2007) Production and properties of a bioemulsifier synthesized by phenanthrene-degrading Penicillum sp. Process Biochem: 42: 310-314. 
10.1016/j.procbio.2006.08.015.

Lunkenheimer K, Wantke KD (1981) Determination of the surface tension of surfactant solutions applying the method of Lecomte du Noüy (ring tensiometer). Colloid \& Polymer Sci 259:354-366. https://doi.org/10.1007/BF01524716

Martínez-Checa F, Toledo FL, Vilchez R, Quesada E, Calvo C (2002) Yield production, chemical composition, and functional properties of emulsifier $\mathrm{H} 28$ synthesized by Halomonas eurihalina strain $\mathrm{H}-$ 28 in media containing various hydrocarbons. Appl Microbiol Biotechnol 58(3):358-63. doi:

10.1007/s00253-001-0903-6. Epub 2001 Dec 11. PMID: 11935188.

Meiners Joan (2020) Ten years later, BP oil spill continues to harm wildlife-especially dolphins. https://www.nationalgeographic.com/animals/article/how-is-wildlife-doing-now-ten-years-after-thedeepwater-horizon

Misra V, Pandey SD (2005) Hazardous waste, impact on health and environment for development of better waste management strategies in future in India. Environ Int 31:417-431.

https://doi.org/10.1016/j.envint.2004.08.005

Mnif I, Ghribi, D (2015) High molecular weight bioemulsifiers, main properties and potential environmental and biomedical applications. World J Microbiol Biotechnol 31(5): 691-706. https://doi.org/10.1007/s11274-015-1830-5

Nerurkar A, Hingurao KS, Suthar H (2009) Bioemulsifiers from marine microorganisms. J Sci Ind Res India. 68. 273-277.

Oliveira J, Michelon, M., Burkert, C (2020) Biotechnological potential of soybean molasses for the production of extracellular polymers by diazotrophic bacteria. Biocatal Agric Biotechnol 25:101609. 101609. 10.1016/j.bcab.2020.101609.

Ortega-de la Rosa ND, Vázquez-Vázquez JL, Huerta-Ochoa S, Gimeno M, Gutierrez-RojasM (2018) Stable bioemulsifiers are produced by Acinetobacter bouvetii UAM25 growing in different carbon sources. Bioprocess Biosyst Eng 41:859-869 https://doi.org/10.1007/s00449-018-1920-5

Pandey P, Arora NK (2020) Prof. Ananda Mohan Chakrabarty: The Superbug Superhero!. Environmental Sustainability 3: 333-335. https://doi.org/10.1007/s42398-020-00117-x

Parthipan P, Preetham E, Machuca LL, Rahman PKSM, Murugan K and Rajasekar A (2017) Biosurfactant and Degradative Enzymes Mediated Crude Oil Degradation by Bacterium Bacillus subtilis A1. Front Microbiol 8:193.10.3389/fmicb.2017.00193

Peele KA, Ch VRT, Kodali VP (2016) Emulsifying activity of a biosurfactant produced by a marine bacterium. 3 Biotech 6:177. https://doi.org/10.1007/s13205-016-0494-7 
Rojo F (2009) Degradation of alkanes by bacteria. Environ microbial 11(10): 2477-2490. https://doi.org/10.1111/j.1462-2920.2009.01948.x

Rosenberg M, Gutnick D, Rosenberg E (1980) Adherence of bacteria to hydrocarbons: A simple method for measuring cell-surface hydrophobicity. FEMS Microbiology Letters 9 (1980): 29 - 33. 10.1111/j.15746968.1980.tb05599.x.

Rosenberg E and Ron EZ (1999) High and low-molecular-mass microbial surfactants. Appl microbiol biotechnol 52(2):154-162. https://doi.org/10.1007/s002530051502

Sabina K, Fayidh MA, Archana G, Sivarajan M, Babuskin S, Babu PA, Radha KK, Sukumar M (2014) Microbial desalination cell for enhanced biodegradation of waste engine oil using a novel bacterial strain Bacillus subtilis moh3. Environ Technol 35(17-20): 2194-203. doi: 10.1080/09593330.2014.896951. PMID: 25145172.

Saha I, Datta S, Biswas D (2020) Exploring the Role of Bacterial Extracellular Polymeric Substances for Sustainable Development in Agriculture. Curr Microbiol 77: 3224-3239. 10.1007/s00284-020-02169-y.

Sana S, Datta S, Biswas D, Sengupta D (2018) Assessment of synergistic antibacterial activity of combined biosurfactants revealed by bacterial cell envelop damage. Biochim Biophys Acta Biomembr 1860 (2): 579-585.

Sana S, Datta S, Biswas D, Auddy B, Gupta M, Chattopadhyay H (2018) Excision wound healing activity of a common biosurfactant produced by Pseudomonas sp. Wound Medicine 23: 47-52 10.1016/j.wndm.2018.09.006.

Selvi PK, Sharma M, Kamyotra JS (2013) Spent oil management and its recycling potential in India inventory and issues.ProcediaEnviron.Sci.18,742-755.

Sengupta D, Datta S, Biswas D (2018) Towards a better production of bacterial exopolysaccharides by controlling genetic as well a physico chemical parameters. Appl Microbiol Biotechnol 102:1587-98. https://doi.org/10.1007/s00253-018-8745-7

Sengupta D, Datta S, Biswas D (2019) Exploring two contrasting surface-active exopolysaccharides from a single strain of Ochrobactrum utilizing different hydrocarbon substrates. J Basic Microbiol 59: 820 833.https://doi.org/10.1002/jobm.201900080

Sengupta D, Datta S, Biswas D (2020) Surfactant exopolysaccharide of Ochrobactrum pseudintermedium C1 has antibacterial potential: Its bio-medical applications in vitro. Microbiol Res. 236.126466.

10.1016/j.micres.2020.126466.

Shete A, Wadhawa G, Banat I, Chopade B (2006) Mapping of patents on bioemulsifier and biosurfactant: A review. J Sci Ind Res India 65: 91-115. 
Singha TK (2012) Microbial Extracellular Polymeric Substances: Production, Isolation and Applications. IOSR Journal of Pharmacy 2: 276-281

Soundari P, Ali A, Guo D, Zhang Z (2020) Waste treatment approaches for environmental sustainability. 10.1016/B978-0-12-819001-2.00006-1.

Toledo F, Gonzalez-Lopez J, Calvo C (2008) Production of bioemulsifier by Bacillus subtilis, Alcaligenes faecalis and Enterobacter species in liquid culture. Bioresource technology 99: 8470-5.

10.1016/j.biortech.2007.08.055.

US EPA (2004) Cleaning up the nation's waste sites: markets and technology trends. Technology Innovation and Field Services Division, Office of Solid Waste and Emergency Response, EPA 542-R-04015. US Environmental Protection Agency, Washington, DC.

US EPA (2018) Managing, Reusing and Recycling Used Oil Technology Innovation and Field Services Division, Office of Solid Waste and Emergency Response, EPA 542-R-04-015. US Environmental Protection Agency, Washington, DC.

Uzoigwe C, Burgess JG, Ennis CJ, Rahman, PKSM (2015) Bioemulsifiers are not biosurfactants and require different screening approaches. Front Microbiol 6:245. doi: 10.3389/fmicb.2015.00245

Vasconcellos, SP, Dellagnezze BM, Wieland A, Klock JH, Santos Neto EV, Marsaioli AJ, Oliveira VM, Michaelis W (2011) The potential for hydrocarbon biodegradation and production of extracellular polymeric substances by aerobic bacteria isolated from a Brazilian petroleum reservoir. World J Microbiol Biotechnol 27(6):1513-8. doi: 10.1007/s11274-010-0581-6. Epub 2010 Oct 13. PMID: 25187151.

Watts A (2013) NMR of Lipids In: Roberts GCK (eds) Encyclopedia of Biophysics. Springer, Berlin, Heidelberg. https://doi.org/10.1007/978-3-642-16712-6_556

Xu X, Liu W, Tian S, Wang W, Qi Q, Jiang P, Gao X, Li F, Li H,Yu H (2018) Petroleum HydrocarbonDegrading Bacteria for the Remediation of Oil Pollution Under Aerobic Conditions: A Perspective Analysis.Front. Microbiol. 9:2885. doi:10.3389/fmicb.2018.02885

Yakimov MM, Timmis KN, Golyshin PN (2007) Obligate oil-degrading marine bacteria. Current Opinion in Biotechnology 18(3): 257-266. 10.1016/j.copbio.2007.04.006

Zarinviarsagh M, Ebrahimipour G, Sadeghi H (2017) Lipase and biosurfactant from Ochrobactrum intermedium strain MZV101 isolated by washing powder for detergent application. Lipids Health Dis 16: 177 (2017). https://doi.org/10.1186/s12944-017-0565-8

Zheng C, He J, Wang Y, Wang M, Huang Z (2011) Hydrocarbon degradation and bioemulsifier production by thermophilic Geobacillus pallidus strains. Bioresour Technol: 102(19):9155-9161. DOI:

10.1016/j.biortech.2011.06.074 
Zheng C, Li Z, Su J, Zhang R, Liu C, Zhao M (2012) Characterization and emulsifying property of a novel bioemulsifier by Aeribacillus pallidus YM-1. J Appli Microbiol 113: 44-51. 10.1111/j.1365-

2672.2012.05313.x.

Zhou JF, Gao P, Dai XH, Cui XY, Tian HM, Xie JJ, Li G, Ma T (2016) Heavy hydrocarbon degradation of crude oil by a novel thermophilic Geobacillus stearothermophilus strain A-2. Int Biodeterior Biodegradation 126: 224-230. 10.1016/j.ibiod.2016.09.031.

\section{Tables}

Table 1 Parameters maintained for bacterial production of surface active compounds

\begin{tabular}{|c|c|c|}
\hline $\begin{array}{l}\text { Variable } \\
\text { parameters } \\
\text { for } \\
\text { production } \\
\text { of SACs in } \\
\text { culture } \\
\text { medium }\end{array}$ & SACs from Bacillus stratosphericus A15 & $\begin{array}{l}\text { SACs from Ochrobactrum } \\
\text { pseudintermedium } \mathrm{C} 1\end{array}$ \\
\hline $\begin{array}{l}\text { Carbon } \\
\text { source }\end{array}$ & $\begin{array}{l}\text { Nonane followed by tetradecane and } \\
\text { hexadecane influence maximum SAC } \\
\text { yield. In waste mineral lubricating oils, } \\
\text { spindle oil followed by cutting and } \\
\text { compressor oil influence maximum SAC } \\
\text { yield. }\end{array}$ & $\begin{array}{l}\text { Hexadecane followed by tetradecane } \\
\text { and nonane influence maximum SAC } \\
\text { yield. In waste mineral lubricating oils, } \\
\text { spindle oil followed by cutting and } \\
\text { compressor oil influence maximum SAC } \\
\text { yield. }\end{array}$ \\
\hline $\begin{array}{l}\text { Percentage } \\
\text { of carbon } \\
\text { source }\end{array}$ & $\begin{array}{l}4 \% \text { of carbon source influences } \\
\text { maximum bacterial growth and SAC } \\
\text { production in culture medium. }\end{array}$ & $\begin{array}{l}2-4 \% \text { can influence growth of the } \\
\text { bacterial strain. } 4 \% \text { of the carbon source } \\
\text { influence maximum SAC production in } \\
\text { culture medium. }\end{array}$ \\
\hline $\begin{array}{l}\mathrm{pH} \text { of } \\
\text { culture } \\
\text { medium }\end{array}$ & slightly alkaline (pH 8) & Neutral (pH 7-7.2) \\
\hline $\begin{array}{l}\text { Aeration } \\
\text { rate }\end{array}$ & 90-92 RPM & 95-100 RPM \\
\hline Temperature & $32-33.5^{\circ} \mathrm{C}$ & $35-37^{\circ} \mathrm{C}$ \\
\hline
\end{tabular}

Table 2 Growth kinetics of bacterial strains Bacillus stratosphericus A15 and Ochrobactrum pseudintermedium $\mathrm{C} 1$ and their adhesion characteristics (cell surface hydrophobicity) to waste spindle oil

Table 3 Chemical composition and $\mathrm{CHN}$ analysis of surface active compounds produced by bacterial strains utilising waste spindle oil (in percentage) 


\begin{tabular}{|lll|}
\hline Bacterial strains & $\begin{array}{l}\text { Cell surface } \\
\text { hydrophobicity (\%) }\end{array}$ & $\begin{array}{l}\text { Maximum absorbance of the culture medium at } \\
600 \mathrm{~nm} \text { during incubation }\end{array}$ \\
$\begin{array}{l}\text { Bacillus stratosphericus } \\
\text { A15 }\end{array}$ & 38 & 0.21 \\
\hline $\begin{array}{l}\text { Ochrobactrum } \\
\text { pseudintermedium } \mathrm{C} 1\end{array}$ & 56 & 0.5 \\
\hline
\end{tabular}

\begin{tabular}{|lcccccc|}
\hline $\begin{array}{l}\text { Surface active compounds } \\
\text { produced by bacterial strains }\end{array}$ & Lipid & Carbohydrate & Protein & Carbon & Hydrogen & Nitrogen \\
\hline $\begin{array}{l}\text { SAC } 3 \text { from Bacillus } \\
\text { stratosphericus A15 }\end{array}$ & 43 & 0.85 & 3.4 & 4.356 & 2.663 & 0.620 \\
\hline $\begin{array}{l}\text { SAC 4 from Ochrobactrum } \\
\text { pseudintermedium C1 }\end{array}$ & 80 & 1.85 & 6 & 12.42 & 3.99 & 0.805 \\
\hline
\end{tabular}

Table 4 Structural elucidation of bacterial surface active compounds by FTIR and NMR spectroscopy.

Table 4a

Table 4b

1. Comparative spectroscopy analysis (FTIR and NMR) of SACs produced from bacterial strains by utilising nonane and hexadecane as carbon source.

2. Comparative spectroscopy analysis (FTIR and NMR) of SACs produced from bacterial strains by utilising waste spindle oil as carbon source.

Table 5 Properties of surface active compounds produced from bacterial strains utilising waste spindle oil as sole carbon source 
Structural SAC 1 from Bacillus

Elucidation stratosphericus A15

1. FTIR

Single

bond

(2500-

$4000 \mathrm{~cm}^{-1}$ )
$-\mathrm{OH}$ stretch (strong and broad, $3300-3450 \mathrm{~cm}^{-1}$ )

$\mathrm{C}=\mathrm{C}$ or carbonyl stretching of amides (medium, $1650 \mathrm{~cm}^{-1}$ )
SAC 2 from Ochrobactrum pseudintermedium $\mathrm{C} 1$

$-\mathrm{OH}$ stretch (broad and strong, $3300-3450 \mathrm{~cm}^{-1}$ ).

$\mathrm{C}=\mathrm{C}$ or carbonyl stretching of amides (medium, $1650 \mathrm{~cm}^{-1}$ )

$-\mathrm{CH}_{3}$ bending $\left(1384 \mathrm{~cm}^{-1}\right), \mathrm{C}-0$ stretch of ether (strong, $1067 \mathrm{~cm}^{-1}$ ) and anomeric carbon (872 $\left.\mathrm{cm}^{-1}\right)$.

Finger

print

region

$(600-1500$

$\mathrm{cm}^{-1}$ )

1. NMR

Upfield

region
$-\mathrm{CH}_{3}$ bending $\left(1384 \mathrm{~cm}^{-1}\right), \mathrm{C}-\mathrm{O}$ stretch of ether (strong, $1055 \mathrm{~cm}$

$\left.{ }^{1}\right)$ and anomeric carbon $\left(877 \mathrm{~cm}^{-}\right.$ $\left.{ }^{1}\right)$.
Signals corresponding to protons of $\mathrm{CH}_{3}$ and $\mathrm{CH}_{2}$ groups (0.8-1.8 ppm), allylic $\mathrm{C}=\mathrm{C}-\mathrm{H}$ group (1.8-2.2 $\mathrm{ppm}$ ) and ether $\mathrm{CH}-\mathrm{OCH}_{3}$ group (3.5-3.4 ppm) are present.
Signals corresponding to protons of $\mathrm{CH}_{3}$ and $\mathrm{CH}_{2}$ groups (0.8-1.8 ppm), allylic $\mathrm{C}=\mathrm{C}-\mathrm{H}$ group (1.8-2.2 ppm). Unsaturated groups or presence of carbonyl group (2.984 ppm) and ether $\mathrm{CH}-\mathrm{OCH}_{3}$ group (3.5-3.4 ppm) are present.

Branching groups absent.

Branching groups i.e., isopropyl groups present (3.690-3.755 ppm)

Towards downfield region 
Structural SAC 3 from Bacillus

elucidation stratosphericus A15

1. FTIR

Single

bond

region

(2500-4000

$\mathrm{cm}^{-1}$ )

Double

bond

(1500-2000

$\mathrm{cm}^{-1}$ )

Fingerprint

region

(600-1500

$\mathrm{cm}^{-1}$ )

1. NMR

Upfield

region

Alkene $-\mathrm{C}=\mathrm{C}$ or carbonyl $-\mathrm{C}=\mathrm{O}$

- $\mathrm{OH}$ stretch (broad and strong, $3431 \mathrm{~cm}^{-1}$ ).

group (variable, $1642 \mathrm{~cm}^{-1}$ )

C-0 stretch of ether (strong, 1065

$\mathrm{cm}^{-1}$ ). Less pronounced bands denoting presence of $\mathrm{C}-\mathrm{N}$ group and anomeric carbon of carbohydrates.
SAC 4 from Ochrobactrum pseudintermedium C1

$-\mathrm{OH}$ stretch (broad and strong, $3388 \mathrm{~cm}^{-1}$ ), $\mathrm{CH}_{2}$ and $\mathrm{CH}_{3}$ groups (sharp, 2925 and $2855 \mathrm{~cm}^{-1}$ ) are present.

Alkene $-\mathrm{C}=\mathrm{C}$ or carbonyl $-\mathrm{C}=\mathrm{O}$ group (variable, $1652 \mathrm{~cm}^{-1}$ )

C-O stretch of ether (strong, $1066 \mathrm{~cm}^{-1}$ ), $-\mathrm{C}-\mathrm{N}$ group (1480-1575 $\mathrm{cm}^{-1}$ ) and anomeric carbon $\left(950-700 \mathrm{~cm}^{-1}\right)$.
Less distinct signal for isopropyl group.

Less pronounced signals for ether

$\mathrm{CH}-\mathrm{OCH}_{3}$ group (3 ppm and $3.839 \mathrm{ppm})$ and anomeric sugars (4.2-4.6 ppm).
Distinct signal for isopropyl group (1.235-1.475 ppm).

Sharp signals for unsaturation (4.162-4.2 ppm), ether $\mathrm{CH}-\mathrm{OCH}_{3}$ group (3.389 ppm) and less pronounced signals for anomeric sugars present (4.1-4.2 ppm) and amide - $\mathrm{NH}$ (7.7-7.8 ppm) present.

Towards

downfield 


\begin{tabular}{|c|c|c|}
\hline Properties of SACs & $\begin{array}{l}\text { SAC } 3 \text { from Bacillus } \\
\text { stratosphericus A } 15\end{array}$ & $\begin{array}{l}\text { SAC } 4 \text { from Ochrobactrum pseudintermedium } \\
\text { C1 }\end{array}$ \\
\hline $\begin{array}{l}\text { Yield of SACs } \\
\text { (mg/L) }\end{array}$ & $150 \mathrm{mg} / \mathrm{L}$ & $300 \mathrm{mg} / \mathrm{L}$ \\
\hline $\begin{array}{l}\text { Tensioactive } \\
\text { property of SACs }\end{array}$ & $\begin{array}{l}\text { Lowers surface tension } \\
\text { from } 72 \mathrm{mN} / \mathrm{m} \text { to } 50 \mathrm{mN} / \mathrm{m} \\
\text { when waste spindle oil is } \\
\text { the carbon source. }\end{array}$ & $\begin{array}{l}\text { Emulsification property against hydrophobic } \\
\text { substrates like engine oil ( } 88 \% \text { ), crude oil (50 } \\
\%) \text {, mustard oil }(37.5 \%) \text {, motor oil ( } 35 \%) \text { and } \\
\text { tetradecane }(12.5 \%) \text {, hexadecane }(10 \%) \text {. }\end{array}$ \\
\hline $\begin{array}{l}\text { Thermal stability } \\
\text { of SACs by } \\
\text { Thermogravimetric } \\
\text { analysis (TGA) }\end{array}$ & $\begin{array}{l}\text { Residual weight of sample } \\
\text { remaining- } 58 \% \\
\text { Total weight loss of sample- } \\
42 \% \\
(\text { Temperature range is } 30- \\
\left.800^{\circ} \mathrm{C}\right)\end{array}$ & $\begin{array}{l}\text { Residual weight of sample remaining- } 66 \% \\
\text { Total weight loss of sample- } 34 \% \\
\text { (Temperature range is } 30-800^{\circ} \mathrm{C} \text { ) }\end{array}$ \\
\hline $\begin{array}{l}\text { Microstructure of } \\
\text { SACs by Scanning } \\
\text { Electron } \\
\text { microscopy (SEM) }\end{array}$ & $\begin{array}{l}\text { Crystalline rod like } \\
\text { structures and few } \\
\text { aggregated globular } \\
\text { structures were observed in } \\
\text { higher magnifications. }\end{array}$ & $\begin{array}{l}\text { Porous matrix like formation with aggregated } \\
\text { globular and crystalline rod like structures } \\
\text { visible in higher magnifications. }\end{array}$ \\
\hline
\end{tabular}

\section{Figures}




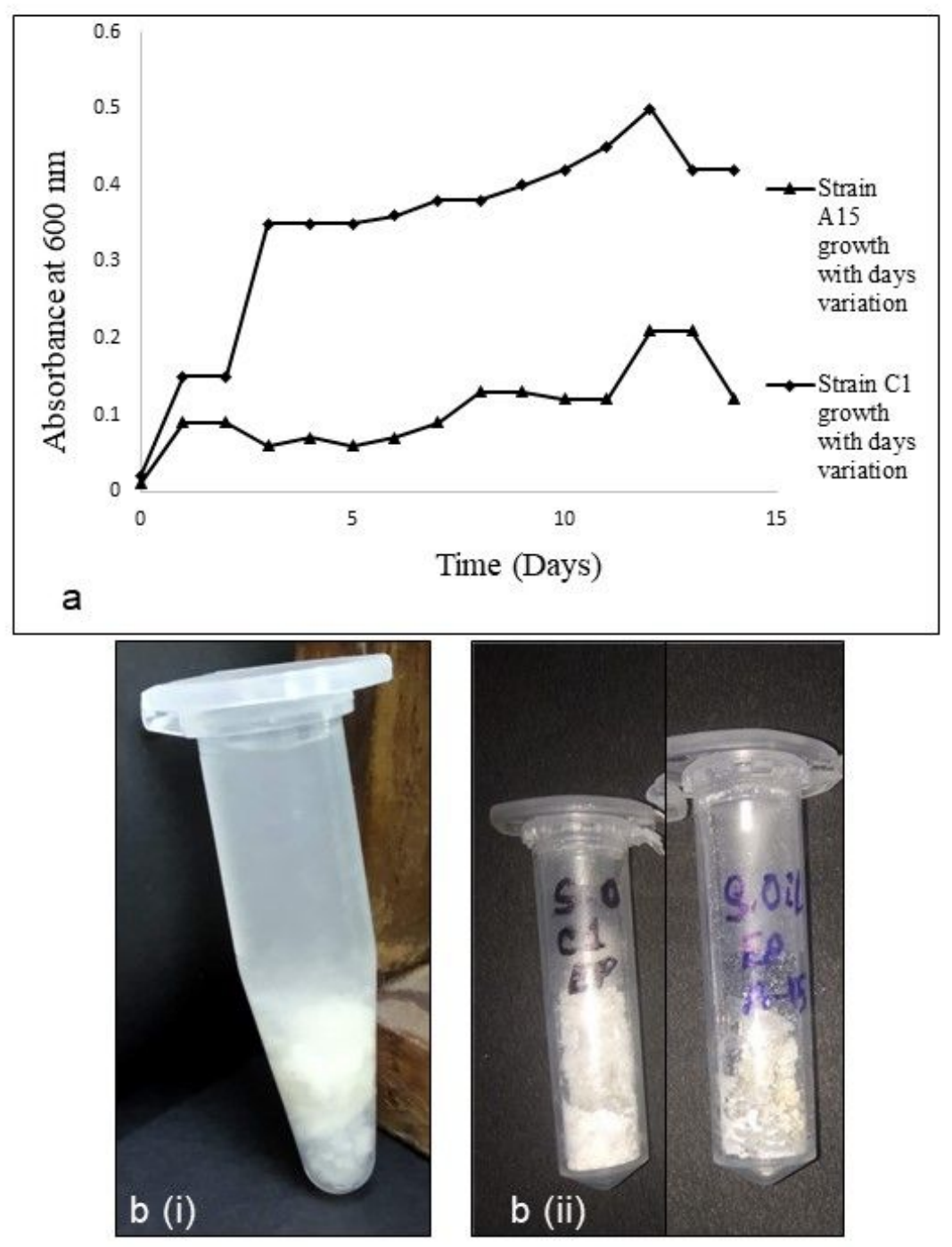

Figure 1

(a) Growth kinetics of Bacillus stratosphericus A15 and Ochrobactrum pseudintermedium C1 in BushnellHaas broth with waste spindle oil as carbon source with variation in days. (b) Isolation of SAC (i) ethanol precipitated SAC (ii) dried SAC. 

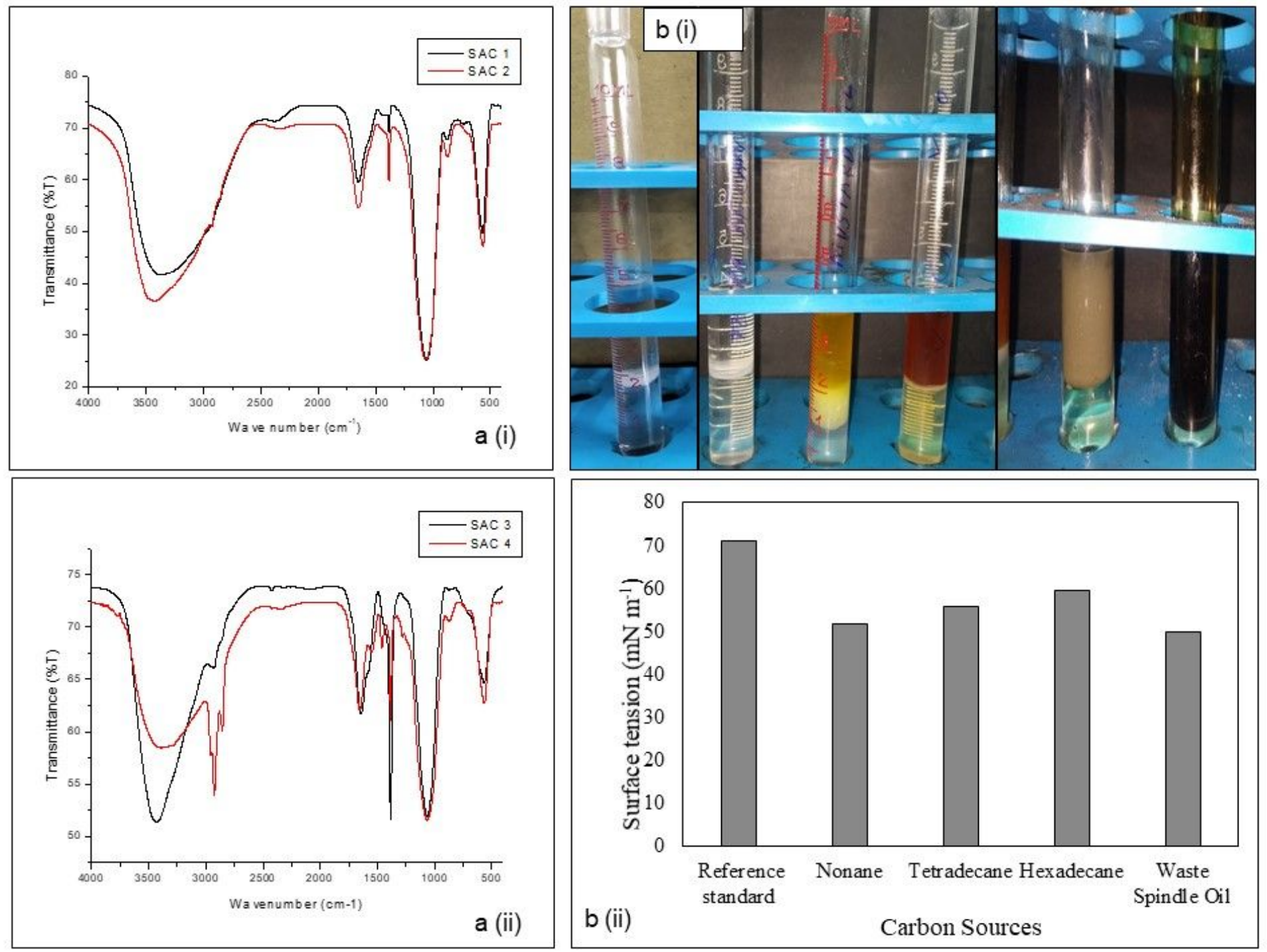

Figure 2

(a) Fourier transform infrared spectra of (i) SAC 1 and SAC 2 produced by Bacillus stratosphericus A15 and Ochrobactrum pseudintermedium $\mathrm{C} 1$ utilizing pure hydrocarbons nonane and hexadecane as sole carbon sources respectively. (ii) SAC 3 and SAC 4 produced by Bacillus stratosphericus A15 and Ochrobactrum pseudintermedium $\mathrm{C} 1$ utilizing waste spindle oil as sole carbon source respectively. (bi) Emulsification potential of surface active compounds produced by strain $\mathrm{C} 1$ utilizing waste spindle oil against hydrophobic substrates hexadecane, tetradecane, mustard oil, vaccum gas oil, crude oil observed after 24 hours. (bii) Surface tension lowering property of surface active compounds produced by strain A15 utilising pure straight chain hydrocarbons (nonane, tetradecane and hexadecane) and waste spindle oil. 

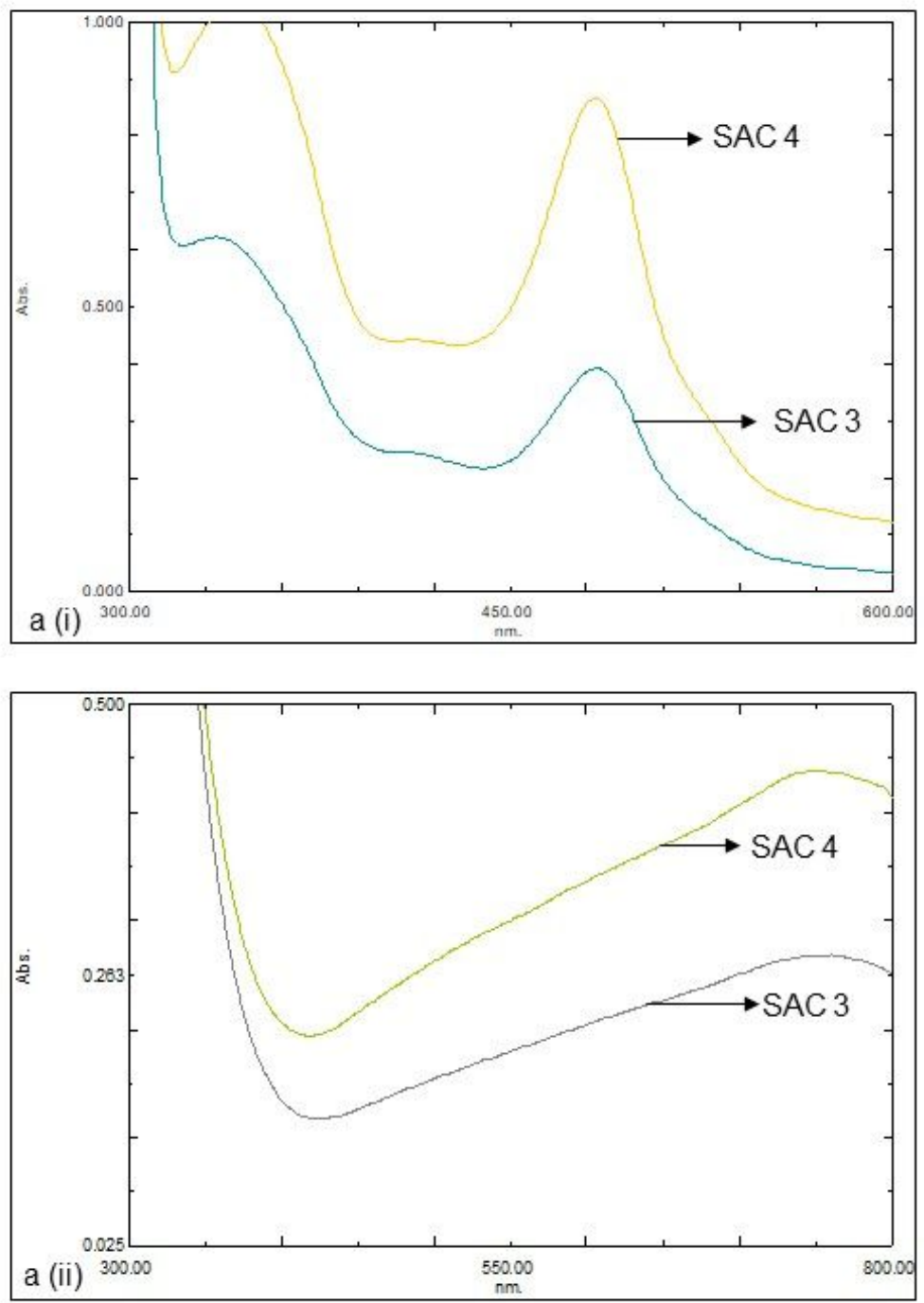

\section{Figure 3}

(a) UV spectrophotometric studies of surface active compounds denoting presence of (i) carbohydrates at $490 \mathrm{~nm}$ by phenol-sulphuric acid method and (ii) proteins at $600 \mathrm{~nm}$ by Lowry's method 


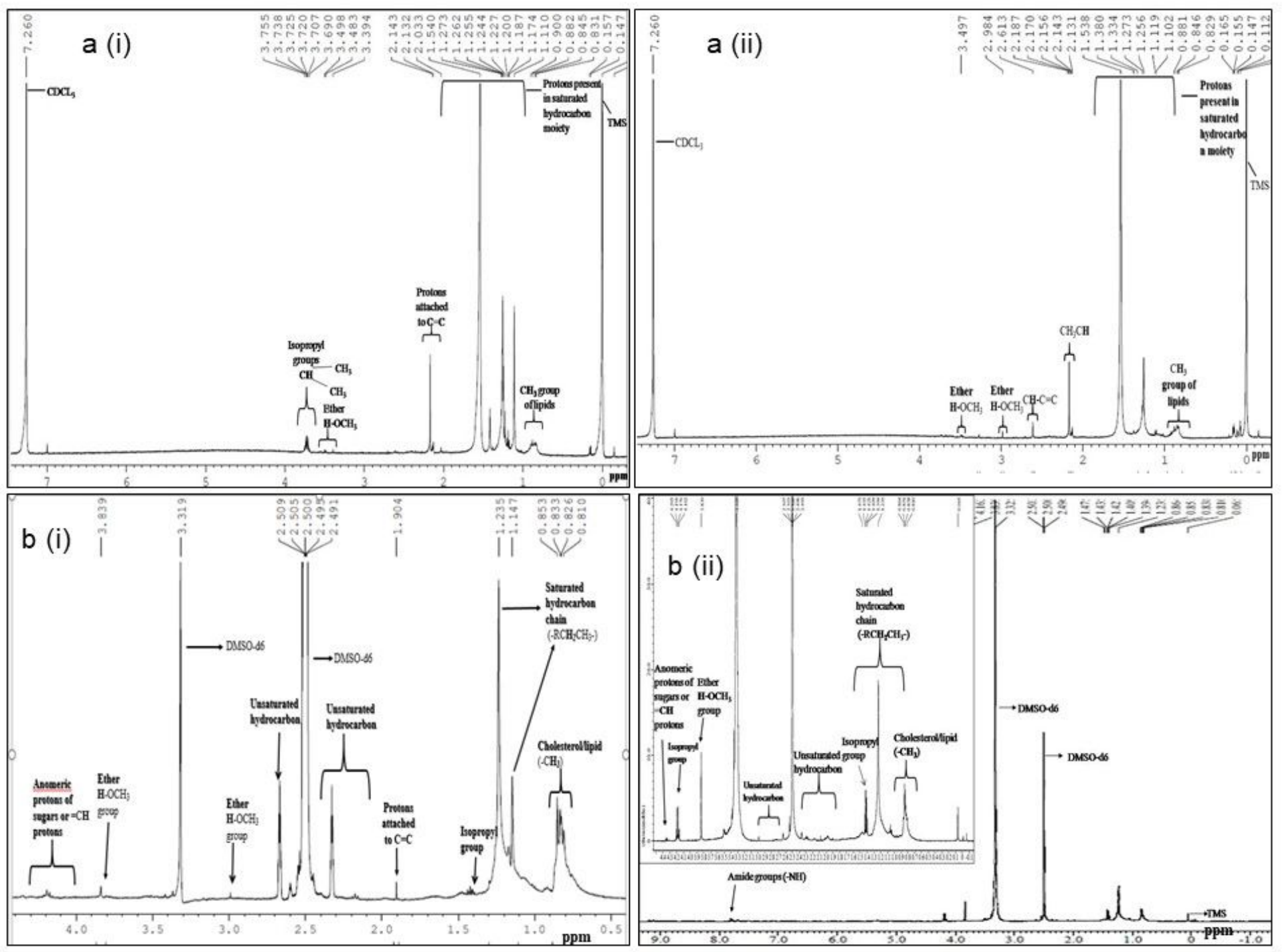

Figure 4

(a) Nuclear magnetic resonance spectra of (i) SAC 1 (ii) SAC 2 produced by Bacillus stratosphericus A15 and Ochrobactrum pseudintermedium $\mathrm{C} 1$ utilizing pure hydrocarbon (nonane and hexadecane). (b) Nuclear magnetic resonance spectra of (i) SAC 3 (ii) SAC 4 produced by Bacillus stratosphericus A15 and Ochrobactrum pseudintermedium $\mathrm{C} 1$ utilizing waste spindle as sole carbon source respectively.

\section{Figure 5}

Scanning electron microscopy images of (a) SAC 3 produced by Bacillus stratosphericus A15 and (b) SAC 4 Ochrobactrum pseudintermedium $\mathrm{C} 1$ at (i) $5 \mathrm{~K}$ (ii) $10 \mathrm{~K}$ magnifications. 


\section{Figure 6}

(a) Thermogravimetric analysis and (b) Differential Thermal analysis curves of SAC 3 and SAC 4 produced by Bacillus stratosphericus A15 and Ochrobactrum pseudintermedium C1. (c) Gas Chromatography-Mass Spectrophotometry chromatograms of (i) before utilisation and after utilisation by bacterial strains (ii) A15 and (iii) C1 respectively (d) Gas Chromatography-Mass Spectrophotometry chromatograms (i) before utilisation by bacterial strains and after utilisation by bacterial strains (ii) A15 and (iii) $\mathrm{C} 1$

\section{Supplementary Files}

This is a list of supplementary files associated with this preprint. Click to download.

- Graphicalabstract.jpg 